\title{
Rancang Bangun Game Edukasi Wawasan Islami Untuk Anak Usia Dini Menggunakan Unity 3D
}

\author{
Salman Al Farisi S a , M. Jasa' Afroni $b$, Efendi S Wiraterunac \\ a Teknik Elektro, Universitas Islam Malang, Kota Malang, Indonesia \\ ${ }^{b}$ Teknik Elektro, Universitas Islam Malang, Kota Malang, Indonesia \\ c Teknik Elektro, Universitas Islam Malang, Kota Malang, Indonesia \\ email: ${ }^{a}$ salmanafs22@gmail.com, ${ }^{b}$ jasaafroni@unisma.ac.id, ${ }^{c}$ efendi.s.wirateruna@unisma.ac.id
}

INFORMASI

ARTIKEL

Sejarah artikel:

Accepted 20 Oktober 2021

Kata kunci: Unity 3D, Android, Game, Edukasi

\begin{abstract}
A B S T R A K
Penelitian ini membahas mengenai perancangan game edukasi untuk anak usia 4-12 tahun di desa Candikuning II, pembangunan aplikasi ini dilakukan untuk berfokus pada media pembelajaran agama berbasis Android, game edukasi "Wawasan Islami" ini dibangun untuk dijadikan sebagai metode pembelajaran agama untuk anak usia dini di desa Candikuning II. Metode penelititan yang diterapkan untuk pengembangan aplikasi adalah metode Waterfall dengan melalui 5 tahapan yaitu Analisis Kebutuhan (Requirement), Perancangan (Design), Penerapan (Impelementation), Pembuktian (Verification) dan Pemeliharaan (Maintenance). Dalam merancang game edukasi ini menggunakan Blender untuk perancangan karakter dan pembuatan gerakan animasinya dan menggunakan Unity untuk game engine. Teknik pengumpulan data menggunakan google forms dengan subjek penelitian untuk anak usia 4-12 tahun. Hasil dari penelitian ini, ialah: (a) Game edukasi “Wawasan Islami” adalah metode pembelajaran agama yang menggunakan Unity 3D. (b) Pengujian kepada ahli media guna menilai tingkat kelayakan game didapatkan hasil sangat layak dengan presentasi kelayakan $89 \%$ dan dari hasil pengujian pengguna dengan rentang usia 4-12 tahun didapatkan hasil sangat layak dengan presentasi kelayakan 93,5\%. Berdasarkan hasil pengujian ahli media dan pengguna dapat disimpulkan bahwa game edukasi “Wawasan Islami” ini layak dijadikan sebagai media pembelajaran agama untuk anak-anak di desa Candikuning II.
\end{abstract}

\section{Pendahuluan}

Agama merupakan suatu landasan untuk manusia menjalani kehidupan sehari-hari, bagi manusia sangatlah penting untuk mempelajari ilmu-ilmu agama sebagai landasan untuk melaksanakan kewajiban dan menjauhi larangan yang diperintahkan oleh Allah Swt. Kurangnya perhatian masyarakat terhadap pentingnya ilmu agama menjadi suatu masalah yang patut diperhatikan. Menurut Undang-undang No.20 Tahun 2003 Tujuan Pendidikan Nasional adalah mengembangkan kemampuan dan membentuk watak serta peradaban bangsa yang bermartabat dalam rangka mencerdaskan kehidupan bangsa, bertujuan untuk berkembangnya potensi peserta didik agar menjadi manusia yang beriman dan bertakwa kepada Tuhan yang Maha Esa, berakhlak mulia, sehat, berilmu, cakap, kreatif, mandiri dan menjadi warga negara yang demokratis serta bertanggung jawab.

Menurut hasil observasi peneliti saat di lapangan di Desa Candikuning II, menemukan informasi permasalahan kurangnya minat anak-anak belajar tentang ilmu agama, antara lain: anak-anak cenderung lebih suka bermain ketimbang belajar, metode pembelajaran yang diterapkan oleh lembaga pendidikan agama setempat dianggap membosankan dan kurangnya perhatian orang tua terhadap pentingnya mengajarkan anak tentang ilmu agama. 
Penggunaan teknologi dipandang membantu menarik minat anak- anak, termasuk dalam mempelajari ilmu-ilmu agama. Karena itu penilitan ini mengusulkan pembuatan game edukasi wawasan islami untuk anak usia dini. Bagi Lembaga Pendidikan Agama hal itu sangat membantu pihak ustadz/ustadzah dalam mengajar anak-anak, karena adanya program game edukasi yang akan dibangun ini merupakan Alternatif untuk menyampaikan sebuah materi karena tidak semua orang bisa menangkap sebuah materi hanya dengan satu metode. Dengan media pembelajaran ini diharapkan dapat membantu anak-anak untuk menangkap materi pelajaran agama [1].

Penelitian yang pertama, Resi Rizki Nanda, Andika Prajana, Khairan AR dan Mulyadi Abdul Wahid(2020) Rancang bangun game edukatif "muslimah adventure" sebagai media dakwah memanfaatkan aplikasi Scratch 2.0. Game ini dibangun menggunakan metode Research \& Development (R\&D) dan Aplikasi Scratch 2.0 dalam mengimplementasikan rancangan yang telah dibuat. Pengguna memberikan respon yang positif karena aplikasi berjalan dengan lancar, loading dalam game cukup cepat, mudah digunakan oleh pengguna dan pengguna mulai terlihat tertarik untuk mempelajari agama dengan metode tersebut [2].

Penelitian yang kedua, Ahmad Fauzan dan Desi Ramayanti(2019) Rancang bangun aplikasi pengenalan kesenian dan budaya di jawa barat berbasis web. Dengan adanya web ini pengguna dapat mempelajari kesenian dan budaya yang ada di Jawa Barat dengan mudah, tampilan website yang dibuat cukup disukai dan pengguna tidak kesulitan untuk membukanya. Aplikasi ini menggunakan framework Materializecss dan jQuery mobile framework untuk desain interface, MySQL sebagai database dan framework PHP Codeigniter guna membuat web terlihat dinamis [3].

Penelitian yang ketiga, Lourent Stefano Mongi, Arie S. M. Lumenta dan Alwin M. Sambul(2018) Rancang Bangun Game Adventure of Unsrat menggunakan Game Engine Unity. Penelitian ini bertujuan untuk memperkenalkan bagaimana kehidupan yang akan dijalani oleh seorang mahasiswa baru di Universitas Sam Ratulangi dan memperkenalkan tempat-tempat yang ada di Universitas Sam Ratulangi. Game ini menggunakan metode Extreme Programming, didesain menggunakan Blender dan diimplementasikan di Unity, game ini diterapkan untuk platform PC. Dengan adanya Game Adventure of Unsrat Mahasiswa baru memiliki gambaran seperti apa kehidupan yang akan mereka jalani pada saat mereka menjadi mahasiswa, pengguna tidak mengalami kesulitan saat memainkannya dan pengguna menyukai game ini [4].

Penelitian yang keempat, Putrie Fortuna RGP, Ahmaddul Hadi (2019) Rancang Bangun Aplikasi Belajar pemrograman dengan Game Education pada Smartphone berbasis Android. Penelitian ini dibangun menggunakan metode pengembangan Prototyping dan menerapkan algoritma game education penyusunan kata. Hasil pengujian dari penelitian Rancang Bangun Aplikasi Belajar pemrograman dengan Game Education pada Smartphone berbasis Android sangat membantu dalam meningkatan keinginan siswa untuk belajar pemrograman, siswa dapat dengan mudah dalam memainkan game tersebut dan game tersebut cukup efektif untuk digunakan sebagai metode pembelajaran [5].

Penelitian yang kelima, Sri Lestari Rahayu dan Pujiati(2018) Penerapan Game Design Document dalam perancangan game edukasi yang interaktif untuk menarik minat siswa dalam belajar bahasa inggris. Penelitian ini dibuat guna menarik anak supaya berkeinginan mempelajari bahasa inggris, dengan metode belajar yang konvensional anak-anak cepat merasa bosan dan malas karena hanya mendengarkan guru menerangkan materi. Game ini dibuat dengan metode waterfall dan Game Design Document(GDD). Guru dapat mengajarkan bahasa inggris dengan mudah menggunakkan metode ini dan Murid dapat mempelajari bahasa inggris dengan baik dan lebih semangat untuk belajar bahasa inggris dengan game edukasi ini pengguna tidak mengalami kesulitan dalam menjalankannya [6].

Penelitian yang keenam, Syamsul Alam H. dan Fata Nidaul K. (2018) Pengujian Aplikasi Pengenalan Dasar Islam dan Surat Pendek Pada Anak berbasis Game Edukasi. Demi menghasilkan anak muda yang berakhlak maka perlu diajarkan ilmu agama mulai dari kecil agar terbiasa untuk mempelajari dan mempraktikkannya. Dengan metode pembelajaran konvensional dianggap kurang efektif untuk mengajarkan agama kepada anak-anak, karena anak-anak cepat merasa bosan bila diajarkan dengan pembelajaran konvensional dan lebih suka bermain daripada belajar, maka dari perlu diterakannya metode pembelajaran alternatif yang bisa menarik minat anak untuk belajar agama. Salah satu cara mengajarkan agama kepada anak-anak yaitu menggunakan game edukasi. Game ini dibangun menggunakan metode pengembangan waterfall dan menggunakan teknik blackbox. Hasil dari pengujian 
game edukasi ini Anak-anak menyukai game tersebut dan mulai memiliki keinginan untuk mempelajari ilmu agama dan game tersebut mudah dijalankan bagi anak-anak [7].

Penelitian yang ketujuh, F.Y. Al Irsyadi1, R Annas dan Y.I. Kurniawan(2019) Game Edukasi Pembelajaran Bahasa Inggris untuk Pengenalan Benda-Benda di Rumah bagi Siswa Kelas 4 Sekolah Dasar. Penelitian ini dibuat guna mempermudah siswa dalam menghafalkan kosakata bahasa inggris dengan menggunakan game edukasi sebagai media pembelajaran. Game ini dibangun menggunakan Construct 2 dan untuk pembuatan game assets menggunakan Corel Draw X7. Hasil pengujian game edukasi ini dapat membantu siswa dalam mengingat kosakata bahasa inggris lebih baik daripada dengan metode pembelajaran konvensional dan siswa merasa antusias untuk belajar bahasa inggris dengan adanya game edukasi ini [8].

\section{Metode Penelitian}

\subsection{Unity 3D}

Unity 3D merupakan software yang digunakan untuk pengembangan game dan Unity $3 \mathrm{~d}$ bisa diterapkan pada multi-platform[9].

\subsection{Android}

Android merupakan operation system yang dipasangkan pada smartphone yang berbasis Linux[10].

\subsection{Android Studio}

Android Studio merupakan Integrated Developement Environment (IDE) yang digunakan untuk pengembangan aplikasi yang berjalan pada platform Android[11].

\subsection{Spesifikasi Alat yang digunakan}

a. Laptop Lenovo ideapad 110

Tabel 2.1 Spesifikasi Notebook

\begin{tabular}{|l|l|l|}
\hline No. & Hardware & Spesifikasi \\
\hline 1 & Prosessor & $\begin{array}{l}\text { AMD A9-9400 Radeon, } \\
2.40 G H z\end{array}$ \\
\hline 2 & RAM & $4 G B$ \\
\hline 3 & Hardisk & 1 TB \\
\hline 4 & Layar & 14 inch \\
\hline
\end{tabular}

b. Smartphone Xiaomi Redmi 5 plus

Tabel 2.2 Spesifikasi Smartphone

\begin{tabular}{|l|l|l|}
\hline No. & Hardware & Spesifikasi \\
\hline 1 & Prosessor & Snapdragon 525 \\
\hline 2 & RAM & $4 \mathrm{~GB}$ \\
\hline 3 & Penyimpanan & $64 \mathrm{~GB}$ \\
\hline 4 & Layar & 5.99 inch \\
\hline
\end{tabular}

\subsection{Flowchart Penelitian}

Kerangka pikir adalah gambar yang menjelaskan tentang bagaimana proses peneliti menentukan metode yang akan digunakan dalam penelitian dan setiap tahapan saling berhubungan. 




\subsection{Flowchart Sistem}

Gambar 2.1 Flowchart Penelitian

Penting untuk merancang flowchart dari sebuah aplikasi. Alur flowchart sistem aplikasi yang adalah sebagai berikut:

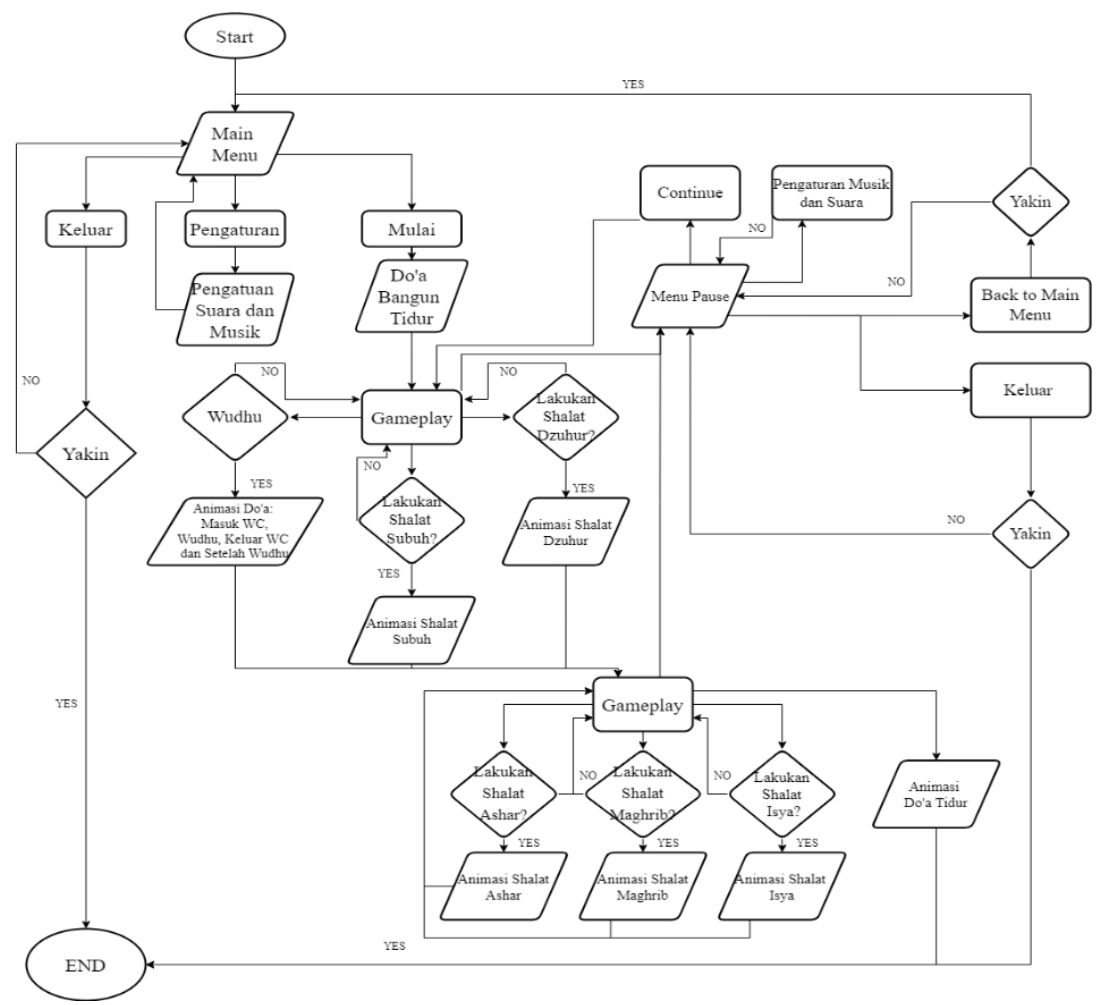

Gambar 2.2 Flowchart Sistem

\subsection{Use Case Diagram}

Pada Aplikasi ini hanya menggunakan satu Actor yaitu User, karena system ini hanya dikhususkan untuk penggunaan pada User dan tidak ada interaksi langsung antara User dan Admin pada saat menjalankan System ini. 


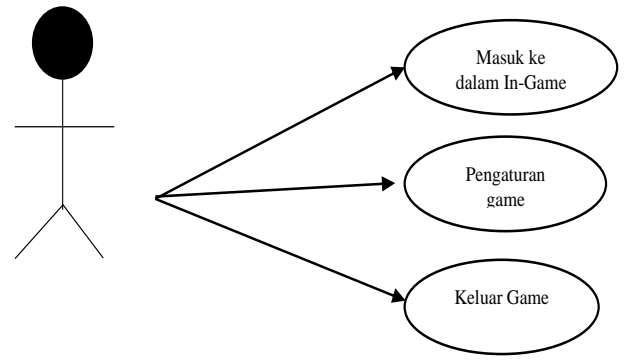

Gambar 2.3 Use Case Diagram

2.8 Perancangan Gameplay

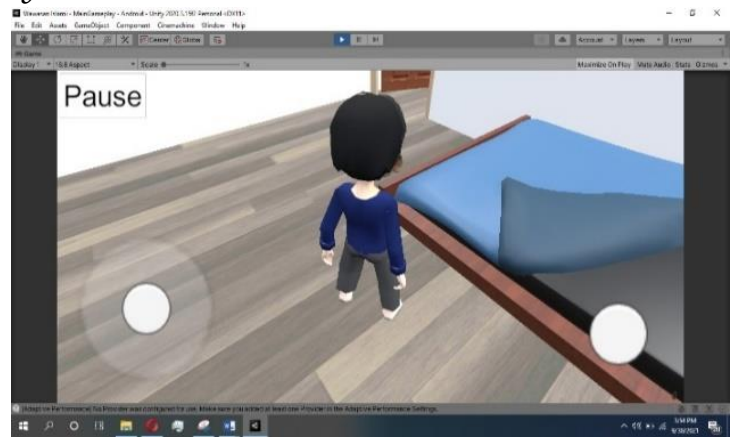

Gambar 2.4 Menu Utama



Gambar 2.5 Perancangan Gameplay

\subsection{Tempat Penelitian dan Waktu Penelitian}

Penelitian dilakukan Pada 13 Desember 2021 di Desa Candikuning Baturiti Tabanan Bali.

\section{Hasil dan Pembahasan}

\subsection{Analisis Kebutuhan Aplikasi}

Analisis kebutuhan yang perlu diterapkan pada game edukasi "Wawasan Islami”, antara lain:

a. Materi Praktik shalat berupa sebuah game pilihan ganda yang ditambahkan dengan video animasi untuk menarik minat anak-anak untuk belajar agama, karena anak-anak bosan belajar menggunakan metode konvensional.

b. Aplikasi diterapkan pada platform Android karena rata-rata masyarakat di Candikuning II lebih banyak menggunakan Smartphone berbasis Android dibandingkan Smartphone dengan OS yang lainnya.

c. Materi yang diajarkan hanya berupa tata cara wudhu, tata cara shalat, do'a masuk kamar kecil, do'a keluar kamar kecil, do'a-do'a setiap gerakan shalat, do'a bangun tidur dan do'a tidur. Karena setiap anak tidak memiliki kesamaan dalam mengingat pelajaran dan supaya anakanak lebih fokus untuk menghafal materi tersebut, karena materi itu akan dipraktikkan setiap hari.

3.2 Membuat Interface Aplikasi

a. Halaman Utama 
Pada gambar 3.1 adalah tampilan home setelah proses log-in ke game, pada tampilan home berisikan tombol mulai untuk berpindah ke gameplay scene dan memulai game, pada tombol pengaturan guna mengubah volume suara dan tombol exit guna keluar dari game.

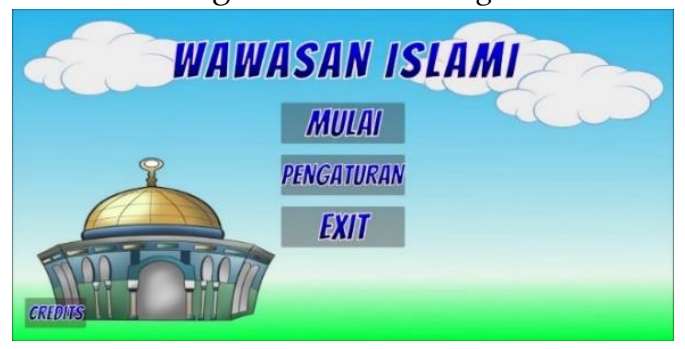

Gambar 3.1 Halaman Utama

b. Video Doa Bangun Tidur

Pada Saat Tombol Mulai dipilih maka Video Bangun Tidur akan di putar setelah Video selesai baru beralih ke Gameplay.



Gambar 3.2 Video Bangun Tidur

c. Tampilan Gameplay

Halaman pada Gambar 3.3 menampilkan bagaimana Gameplay yang disajikan dan pada halaman ini User menggerakkan Karakter di dalam Game, pada Halaman ini terdapat Analog untuk penggerak Karakter dalam Game, Tombol Pause untuk menghentikan Game sejenak dan pengatur Kamera.

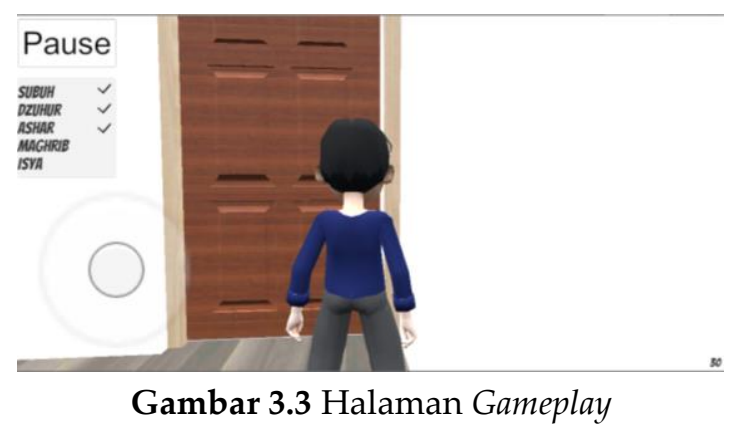

d. Tampilan Event Masuk Kamar Kecil

Halaman pada Gambar 3.4 menampilkan event untuk masuk ke Kamar Kecil, event ini terjadi apabila Karakter mendekati Pintu Kamar Kecil dan terdapat Tombol "IYA" untuk menampilkan Materi dan Tombol "TIDAK" untuk membatalkan event.

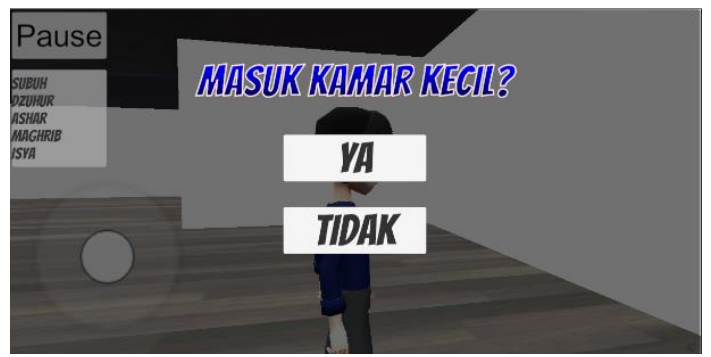

Gambar 3.4 Pop up Event Kamar Kecil

e. Tampilan Event Masuk Kamar Kecil diputar

Halaman pada Gambar 3.5 akan ditampilkan jika pada Event Masuk Kamar Kecil yang dipilih tombol "IYA" 


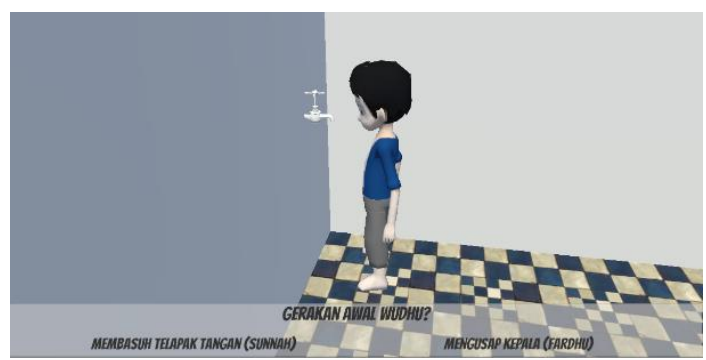

Gambar 3.5 Event Kamar Kecil

\subsection{Tahap Pengujian}

a. Pengujian Responden Pengguna

Hasil pengujian yang diperoleh dari responden pengguna yang berjumlah 15 orang dengan keterangan pada tabel 3.1 sebagai berikut :

Tabe1 3.1 Hasil Skor Pengujian Pengguna

\begin{tabular}{|l|l|c|c|c|}
\hline No & \multicolumn{1}{|c|}{ Penilaian } & Poin & $\begin{array}{c}\text { Jumlah } \\
\text { skor }\end{array}$ & Jumlah \\
\hline 1. & Sangat Baik & 5 & 164 & 820 \\
\hline 2. & Baik & 4 & 74 & 296 \\
\hline 3. & Cukup & 3 & 2 & 6 \\
\hline 4. & Kurang & 2 & 0 & 0 \\
\hline 5. & $\begin{array}{l}\text { Sangat } \\
\text { Kurang }\end{array}$ & 1 & 0 & 0 \\
\hline \multicolumn{4}{|c|}{ Skor Total (X) } & 1.122 \\
\hline
\end{tabular}
a. Poin 1 = Sangat Kurang
b. Poin 2 = Kurang
c. Poin 3=Cukup Baik
d. Poin $4=$ Baik
e. Poin $5=$ Sangat Baik

Setelah memperoleh Mean ideal (skor rata-rata) tiap instrumen setelah itu menghitung presentasi kelayakan dengan rumus berikut ini:

Rumus perhitungan pencarian presenatase:

$$
\text { Pesentase Kelayakan }(\%)=\frac{\text { Skor yang diobservasi }}{\text { Skor yang diharapkan }} \times 100 \%
$$

Jumlah butir kriteria $=16$

Menghitung nilai tertinggi :

$\mathrm{a}=$ Jumlah butir kriteria $\mathrm{x}$ jumlah responden $\mathrm{x}$ skor tertinggi

$$
\begin{aligned}
& =16 \times 15 \times 5 \\
& =1.200
\end{aligned}
$$

Menghitung nilai terendah

$\mathrm{b}=$ Jumlah butir kriteria $\mathrm{x}$ jumlah responden $\mathrm{x}$ skor terendah

$$
\begin{aligned}
& =16 \times 15 \times 1 \\
& =240
\end{aligned}
$$

Menghitung rata-rata (Mean) ideal

$\overline{\mathrm{X}}$

$$
\begin{aligned}
& =\frac{1}{2} \times(\mathrm{a}+\mathrm{b}) \\
& =\frac{1}{2} \times(1.200+240) \\
& =720
\end{aligned}
$$

Menghitung simpangan baku ideal

SDi

$$
\begin{aligned}
=\frac{1}{3} \times \frac{1}{2} & \times(\mathrm{a}-\mathrm{b}) \\
& =\frac{1}{3} \times \frac{1}{2} \times(1.200-240) \\
& =160
\end{aligned}
$$


Tabel 3.2 Perhitungan Skala Likert

\begin{tabular}{|l|l|c|}
\hline No & Score Range & Katergori \\
\hline 1 & $\overline{\mathrm{x}}+(1,80 \times 160)<\mathrm{X}$ & Sangat Layak \\
& $1.008<\mathrm{X}$ & \\
\hline 2 & $\begin{array}{l}\mathrm{X}+(0,6 \times 160)<\mathrm{X} \leq \overline{\mathrm{X}}+ \\
(1,80 \times 160)\end{array}$ & \\
& $816<\mathrm{x} \leq 1.008$ & \\
\hline 3 & $\begin{array}{l}\mathrm{x}-(0,6 \times 160)<\mathrm{X} \leq \overline{\mathrm{X}}+ \\
(0,6 \times 160)\end{array}$ & Cukup Layak \\
& $624<\mathrm{X} \leq 816$ & \\
\hline
\end{tabular}

$$
\begin{aligned}
& =\frac{1.122}{1,200} \times 100 \% \\
& =93,5 \%
\end{aligned}
$$

Dari perhitungan presentasi kelayakan diperoleh hasil 93,5\% dan perhitungan menggunakan skala likert diperoleh hasil nilai $\mathrm{X}=1.122$. Dengan demikian game edukasi "Wawasan Islami" masuk ke dalam kategori sangat layak.

\section{Kesimpulan}

Berdasarkan hasil penelitian dan pembahasan dapat disimpulkan sebagai berikut:

1. Game edukasi ini dibuat dengan menggunakan software Blender untuk perancangan animasi karakter dan dijalankan menggunakan Unity fitur yang diberikan berupa tata cara wudhu, doa wudhu, tata cara shalat dan doa-doa dalam shalat. Dengan adanya software tersebut, game yang dibangun yaitu "Wawasan Islami" diharapkan dapat memenuhi kebutuhan dari objek penelitian.

2. Hasil pengujian efektivitas pengajaran agama menggunakan game edukasi "Wawasan Islami" meliputi pengujian ahli media dan pengujian responden pengguna. Hasil uji ke ahli media diperoleh hasil presentase kelayakan $89 \%$. Dan hasil uji responden pengguna diperoleh hasil kelayakan 93,5\%. Dengan demikian game edukasi "Wawasan Islami" dapat dikategorikan sangat layak untuk dijadikan metode pembelajaran alternatif.

\section{DAFTAR PUSTAKA}

[1] T. UNIWARA, Prosiding Transformasi Pembelajaran Nasional Vol 1: "PELUANG DAN TANTANGAN PEMBELAJARAN DIGITAL DI ERA INDUSTRI 4.0 MENUJU ERA 5.0." Prosiding Transformasi Pembelajaran Nasional (Pro-Trapenas), 2021.

[2] R. R. Nanda, A. Prajana, K. Ar, and M. A. Wahid, "Jurnal Phi Rancang bangun game e dukatif ' muslimah adventure' sebagai media dakwah," J. Phi J. Pendidik. Fis. dan Fis. Terap., vol. 1, no. 1, pp. 1-6, 2020.

[3] T. Informatika and F. I. Komputer, “DAN BUDAYA DI JAWA BARAT BERBASIS WEB Indonesia memiliki berbagai macam warisan budaya dan tradisi yang sudah meresap di kehidupan masyarakat hingga telah berlangsung turun temurun dari," vol. 12, no. 1, 2019.

[4] L. S. Mongi, A. S. M. Lumenta, and A. M. Sambul, “Rancang Bangun Game Adventure of Unsrat Menggunakan Game Engine Unity," J. Tek. Inform., vol. 13, no. 1, 2018, doi: 10.35793/jti.13.1.2018.20191.

[5] P. F. (Universitas N. P. RGP and A. (Universitas N. P. Hadi, "Rancang Bangun Aplikasi Belajar Pemrograman Dengan Game Education Pada Smartphone Berbasis Android," VotekTEKNIKA, vol. 7, no. 3, p. 3, 2019, [Online]. Available:

http://ejournal.unp.ac.id/index.php/voteknika/article/view/105086.

[6] S. L. Rahayu and F. Fujiati, "Penerapan Game Design Document dalam Perancangan Game Edukasi yang Interaktif untuk Menarik Minat Siswa dalam Belajar Bahasa Inggris," J. Teknol. Inf. dan Ilmu Komput., vol. 5, no. 3, p. 341, 2018, doi: 10.25126/jtiik.201853694. 
[7] S. A. Haris and F. N. Khasanah, "Pengujian Aplikasi Pengenalan Dasar Islam dan Surat Pendek pada Anak Berbasis Game Edukasi," Inf. Syst. Educ. Prof., vol. 2, no. 2, pp. 167-176, 2018.

[8] F. Y. Al Irsyadi, R. Annas, and Y. I. Kurniawan, "Game Edukasi Pembelajaran Bahasa Inggris untuk Pengenalan Benda-Benda di Rumah bagi Siswa Kelas 4 Sekolah Dasar," J. Teknol. dan Inf., vol. 9, no. 2, pp. 78-92, 2019, doi: 10.34010/jati.v9i2.1844.

[9] R. Prabowo, M. J. Afroni, and O. Melfazen, “Aplikasi Game Edukasi Android Mengenal Bahasa Inggris 'Kids ABC' untuk Murid Tingkat Sekolah Dasar," JTE (Jurnal Tek. Elektro Unisma), vol. 13, no. 1, pp. 1-6, 2021.

[10] I. Afrianto and R. M. Furqon, “The Herbalist Game Edukasi Pengobatan Herbal Berbasis Android," J. Sist. Inf. Bisnis, vol. 8, no. 2, p. 27, 2018, doi: 10.21456/vol8iss2pp27-34.

[11] A. Setiawan, B. Minto, and F. Badri, "RANCANG BANGUN APLIKASI MANAJEMEN ORGANISASI MAHASISWA DENGAN METODE PROTOTYPING ( FAKULTAS TEKNIK UNIVERSITAS ISLAM MALANG )," vol. 1, no. 1, pp. 36-48, 2021. 